\begin{tabular}{|c|c|}
\hline \multirow[t]{4}{*}{ Citation } & Jeroen Maesschalck, (2015) \\
\hline & Ethics and Administrative Reform \\
\hline & In: Bearfield, D.A. \& Dubnick, M.J. (Eds.), Encyclopedia of Public \\
\hline & $\begin{array}{l}\text { Administration and Public Policy, 3rd Ed. New York: Taylor \& Francis, 1216- } \\
1219 .\end{array}$ \\
\hline Archived version & $\begin{array}{l}\text { Author manuscript: the content is identical to the content of the published } \\
\text { paper, but without the final typesetting by the publisher }\end{array}$ \\
\hline Publisher homepage & http://taylorandfrancis.com/ \\
\hline Author affiliation & $\begin{array}{l}\text { Jeroen Maesschalck, Leuven Institute of Criminology, Faculty of Law, KU } \\
\text { Leuven (University of Leuven), Belgium }\end{array}$ \\
\hline Author contact & jeroen.maesschalck@law.kuleuven.be \\
\hline & +32(0) 16325558 \\
\hline IR & https://lirias.kuleuven.be/handle/123456789/533684 \\
\hline
\end{tabular}

(article begins on next page) 


\title{
Ethics and Administrative Reform
}

- DOI: $10.1081 /$ E-EPAP2-120024736

- Authors: Jeroen Maesschalck, Leuven Institute of Criminology, KU Leuven (University of Leuven), Belgium

\begin{abstract}
:
The implementation of 'new public management' as well as of more recent reforms such as those associated with network governance have led to serious concerns, both among academics and practitioners, about their impact upon the ethics of public servants. This contribution argues that these discussions can essentially be reduced to a debate between three fundamental positions: new public management (NPM), traditional public administration (TPA), and new public service (NPS). While the three positions clearly diverge in their normative ideas about the desirability of particular types of ethical behavior and the seriousness of types of unethical behavior, their empirical claims are rather complementary. Together, they reflect an important insight in management: each approach, however well intended, carries with it the risk of particular excesses.
\end{abstract}

\section{Keywords}

- New public management,

- New public service,

- Ethics management,

- Accountability,

- Integrity,

- Corruption,

- Reform,

- Reinvention

\section{Introduction}

As long as there has been a public sector, there have been attempts to reform it. This contribution will primarily focus on the wave of reforms that have impacted the public sectors of many countries throughout the world since the 1980s and that have often been described as 'new public management' (NPM). There is no broad consensus on the exact definition of NPM. Essentially, it refers to reforms that aim to introduce ideas and practices from the private sector into public sector organizations. This includes the introduction of performance management systems, more responsibility and accountability for public managers, more competition in the public sector, the introduction of quality management techniques, etc. [1] [2].

The implementation of NPM reforms in governments throughout the world has caused concern, both among academics and practitioners, about their impact upon the ethics of public servants. One source for such concerns have been highly publicized scandals, typically about individuals behaving unethically and often also illegally. Typically, these individuals were initially seen as exemplars or even heroes, who successfully managed to escape bureaucratic constraints in order 
to produce results and 'get things done' until it was discovered that their escaping bureaucratic constraints also included manifest illegal behavior. It is argued that these excesses are caused by NPM reforms because the NPM-type rhetoric and reforms provided these individuals not only with the opportunity to perform such behavior but also with the moral mindset to justify it. However, NPM reforms are also alleged to lead to more collective or even systemic unethical behavior. A case in point are 'creaming' strategies, a typical perverse effect of performance management systems. Suppose that the public servants who are in charge of vocational training of unemployed people would be assessed (and paid) on the basis of their 'success rate,' defined as the number of applicants who are able to obtain a job following the training. It is not unlikely that these public servants would only allow the most job-ready applicants into their training courses. This would leave a considerable category of unemployed people without training, which is unlikely to be an intended effect of this policy. This is just one example of the ethically undesirable consequences that are alleged to be fostered by NPM reforms.

Ethical concerns have not been limited to NPM reforms, however. Concerns have also been expressed about more recent reforms, such as those associated with network governance. A case in point is the 'new public governance', which focuses 'upon interorganizational relationships and upon the governance of processes, stressing service effectiveness and outcomes that rely upon the interaction of [public service organizations] with their environment' [3]. Osborne, who coined the term 'new public governance', warns that the value base within these networks 'is often dispersed and contested' [3]. These networks are typically weak on control mechanisms or procedural safeguards. This in turn makes it more difficult to hold the central actors in those networks accountable if they commit unethical behavior. Also, it becomes increasingly difficult to identify the ethical standards against which those central actors should be judged, because these networks typically blur boundaries between different sectors. Should the traditional values of the public sector still apply to them or should they, instead, be judged against ethical standards from the private (profit or not for profit) sector? One could particularly wonder whether traditional procedural concerns like due process or equal treatment are as desirable and, if so, enforceable in a context of network governance as they are in a traditional government bureaucracy.

This contribution argues that these debates can essentially be reduced to three fundamental positions: new public management (NPM), traditional public administration (TPA), and new public service (NPS). It briefly explains the three positions and then proposes two roads to a more nuanced debate.

\section{Three fundamental positions in the debate}

The answer of public administration scholars to the ethical concerns about NPM is a discussion that can, in terms of Hood and Jackson, be conceived of as a 'doctrinal debate'[4]. Doctrines are "specific maxims about administrative whos, hows, and whats"; they "denote specific ideas about what should be done in administration" [4]. The doctrines mentioned in the NPM-ethics debate can essentially be organized in three fundamental positions. The following paragraphs will summarize those positions. Although this overview will focus on the recent debate over the ethical impact of NPM reforms, it is in fact much broader because those against NPM reforms propose their own alternative, which is then in turn criticized by the other participants in the 
debate. Moreover, these positions are rooted in a broader administrative philosophy, thus making this debate a contemporary version of older debates [5].

\section{New public management}

The first position is anchored in the NPM administrative philosophy. NPM's heyday started with the seminal 1991 article of Christopher Hood [2] who conceived of NPM as a set of doctrinal ideas with a certain degree of coherence, (i.e., an administrative philosophy) that has come to be widely accepted. Hood [6] mentions six doctrines to define the NPM administrative philosophy.

- 'Unbundle' the public service into corporatized units organized by product.

- Ensure more contract-based competitive provision, with internal markets and term contracts.

- Emphasize private sector styles of management practice.

- Put more emphasis on visible 'hands-on' top management

- Make performance standards and measures explicit, formal, and measurable.

- Emphasize on output controls.

Other characteristics, such as separating political decision making from direct management quality management and customer service focus are also often associated with NPM [7].

The NPM proponents' consideration of the ethical consequences of administrative reform is rather modest. Sometimes, NPM proponents emphasize how competition mechanisms can reduce corruption, e.g., by lessening the opportunities of public servants to corruptly charge monopoly rents[8]. More often, however, they remain silent on the topic of ethics [9]. The assumption seems to be that ethical behavior will naturally follow from an implementation of NPM reforms. Ethical behavior is then mainly understood as behavior that strengthens "the three E's" (economy, efficiency, and effectiveness).

\section{Traditional public administration}

The second position is at the other side of the spectrum. It is rooted in 'traditional public administration" (TPA), also referred to as the 'old public administration'[10] or the 'orthodox model'[11]. Of course, TPA contains many different ideas and it would be incorrect and simplistic to present them as one monolithic block of doctrines and justifications without any internal debates or changes. Yet, a broadly shared administrative doctrine of TPA with regard to ethics management prescribes that the organizational processes be organized in such a way that "the individual ethical choice is limited to choosing to follow the rules (the ethical thing to do) or 
to violate them by commission or omission (unethical acts)" [11]. In the debate over the ethical effects of NPM reforms, the proponents of TPA have "throw[n] up their hands in horror at recent trends, seeing them as marking the destruction of the public service ethos"[12]. In the United Kingdom, Chapman and O'Toole [13-14] argued for a return to the traditional civil service ethos and to the traditional concept of 'public duty'. Writing from the US context, Frederickson [15] also forcefully expresses his concerns about the ethical consequences of NPM innovations such as marketizing, privatizing, or contracting out, and he argues for a 're-regulation'. One particularly prominent strand in the TPA tradition emphasizes the legal point of view and criticizes NPM "for its sometimes cavalier treatment of the rule of law, especially its free and easy slogans about eliminating red tape and letting managers manage"[16].

\section{New public service}

The third position is derived from what has been labeled the 'new public service' (NPS) [10], but has also been described as the 'classical' or 'Aristotelian' mode of organizing [17] or the 'communitarian/citizen alternative' [18]. Denhardt and Denhardt present the NPS approach as a viable third alternative for the observed dichotomy between 'the old public administration' and NPM. Rather than traditional bureaucracies that are controlled from the top down and largely closed for citizens, Denhardt and Denhardt propose new mechanisms in which "the primary role of the public servant is to help citizens articulate and meet their shared interests rather than to attempt to control or steer society"'[10]. In order to achieve this overall aim, Denhardt and Denhardt propose seven doctrines that embody their administrative philosophy:

- Serve, rather than steer.

- The public interest is the aim, not the by-product.

- Think strategically, act democratically.

- Serve citizens, not customers.

- Public servants should be attentive to the law, community values, political norms, professional standards, and citizen interests.

- Value people, not just productivity.

- Value citizenship and public service above entrepreneurship.

As for the debate over the impact of NPM reforms on ethics, those writing from an NPS point of view largely join the TPA advocates in their negative assessment of the ethical consequences of NPM reforms, but propose a different solution. Specifically, Denhardt and Denhardt argue that public sector organizations should be organized in such a way that public servants are not responsive to 'constituents and clients' (TPA), nor to 'customers' (NPM), but to 'citizens'. 
Citizens are described as those people who "demonstrate their concern for the larger community, their commitment to matters that go beyond short-term interests and their willingness to assume personal responsibility for what happens in their neighborhoods and the community" [10]. To make public servants capable of being responsive to these kinds of citizens, the doctrines described above should be the guide. Several other authors have criticized NPM from an NPS point of view. Although he also used TPA arguments to criticize NPM (see above), most of Frederickson's prescriptive claims (particularly in "The Spirit of Public Administration" [19]) rather correspond to the NPS administrative philosophy. One example of this is his plea for a "combination of patriotism (the love of the regime values) with benevolence (the love of others)" [19]. Gawthrop [20] contrasts the 'democratic spirit' with the NPM-type 'entrepreneurial spirit' and argues that the former should prevail. He also strongly criticizes the TPA-style 'ethics of compliance' he observed in the US public administration for leading to a soulless public administration, obsessed with procedural correctness. He argues that public servants should have a personal responsibility, with 'service as the center of value'.

\section{Conclusion: towards a more nuanced debate}

As the academic debate evolves and experience with the practice of these reforms grows, the debate also becomes more nuanced. This occurs particularly in two ways.

First, both academics and practitioners increasingly understand that there is some truth in all three positions mentioned above. While the NPM literature is ripe with success stories of NPM reforms and convincing examples of the undesirable effects of traditional bureaucracies, the TPA and NPS proponents can easily point at the scandals that followed NPM reforms. While the three positions clearly diverge in their normative ideas about the desirability of particular types of ethical behavior and the seriousness of types of unethical behavior, their empirical claims are indeed rather complementary. Together, they reflect an important insight in management: each approach, however well intended, carries with it the risk of particular excesses. Kathryn Denhardt [21] formulated this aptly in the context of ethics management: "Every organizational structure can promote an ethical stance yet at the same time contain the seeds of pathology." In order to avoid this problem, academics and practitioners increasingly attempt to combine the three fundamental positions. The permanent tension between the approaches that follows from this then helps to avoid blind spots for the potential negative effects of one particular approach. According to this strategy, the decision is not which of the three fundamental positions should be applied, but how all three of them should be combined. More recent versions of (academic discourse about) administrative reform can indeed be considered attempts at combining the three fundamental positions. Osborne's 'new public governance', for example, contains important elements listed above under NPS such as its emphasis upon service delivery within a plural system, but combines these with elements of TPA and NPM [22]. Likewise, while Dunleavy et al.'s 'digital era's governance' is presented as an alternative to NPM, it also maintains doctrines "at a tangent to NPM priorities and orientations" [23]. Finally, Pollit and Bouckaert's neoWeberian state largely relies on TPA-style doctrines, but aims to "modernize the traditional state apparatus so that it becomes more professional, more efficient, and more responsive to citizens" [24], thus adding both NPM- and NPS-elements. While such hybrids of the three fundamental positions might be better at avoiding blind spots and thus reduce ethical risks, they certainly do not guarantee absence of ethical problems. Reforms associated with 'new public governance', for 
example, have been criticized for their blurred accountability and lack of clarity about the ethical behavior required from the main actors (see above). Thus, while combining insights from the three positions can help to reduce ethical risks, it is certainly not sufficient.

The second evolution in the debate is complementary to the first. It is the growing understanding that ethics management would be a useful way to prevent many of the ethical risks associated with NPM or other types of reform. Ethics management, in this context, refers to instruments (e.g. ethics codes, ethics training, whistle-blowing arrangements, effective disciplinary procedures) and structures (e.g. ethics advisors, enforcement officers) to avoid unethical behavior and stimulate ethical behavior. Traditionally, the ethics management literature distinguishes between the compliance and integrity approaches to ethics management and prescribes that both should be applied for ethics management to be effective [25]. The 'compliance' approach to ethics management emphasizes the importance of controls on the behavior of public servants (e.g., legislation, strict behavioral ethics codes, and extensive control mechanisms) and thus comes very close to TPA. The 'integrity' approach assumes that, rather than controlled, public servants should be supported and stimulated in behaving ethically. This integrity approach is "based on aspirations, relies on incentives, and encourages good behavior rather than policing and punishing errors and wrongdoing" [26]. and thus strongly relies on NPS doctrines. Rather than limiting public servants' discretion, as the compliance approach would have it, the integrity approach would support public servants in dealing with their discretion. Following this second evolution in the debate, one could accept NPM and other types of reforms, but at the same time require that these are combined with ethics management that combines a considerable degree of TPA (the 'compliance' approach) to delineate the discretion, with a considerable degree of NPS (the 'integrity' approach) to stimulate public servants to use the remaining discretion ethically.

In sum, rather than uncritically accepting NPM reforms or radically criticizing them from either a TPA- or NPS-perspective, it might be more fruitful to combine insights from the three perspectives. This could be done by taking the three perspectives into consideration when designing a particular reform, as more recent labels, such as new public governance, the neoWeberian state and digital era governance, indeed suggest. This could also be done by combining NPM reforms with instruments of ethics management, carefully balancing the compliance and integrity approaches. Such complex balancing exercises do not guide us to clear-cut and neat solutions, but they do reduce the risk of administrative reforms leading to ethical disaster.

\section{References}

1. Pollitt, C.; Bouckaert, G. Public Management Reform. A Comparative Analysis, New Public Management, Governance, and the Neo-Weberian State. Third edition; Oxford University Press: Oxford, 2011.

2. Hood, C. A public management for all seasons? . Public Administration 1991, 69 ( 1 ) 3 -19 . 
3. Osborne, S.P. (ed.) The New Public Governance? Emerging Perspectives on the Theory and Practice of Public Governance; Oxon: Routledge, 2010, 9.

4. Hood, C.; Jackson, M. Administrative Argument; Aldershot : Darthmouth , 1991 .

5. Maesschalck, J. The impact of new public management reforms on public servants' ethics: towards a theory. Public Administration 2004, 83 (2), 465-489.

6. Hood, C. Explaining Economic Policy Reversals ; Open University Press : Buckingham, Philadelphia , 1994.

7. McLaughlin, K.; Osborne S.P.; Ferlie, E. New Public Management. Current Trends and Future Prospects. London: Routledge, 2002, 9, referred to in Van de Walle, S.; Hammerschmid, G. (2011). The impact of new public management: challenges for coordination and cohesion in the public sectors. Halduskultuur - Administrative Culture 2011, 12 (2) 190-209.

8. Klitgaart, R. Controlling Corruption ; University of California Press : Los Angeles, CA, 1988 .

9. Menzel, D.C. The morally mute manager: fact or fiction? . Public Pers. Manage. 2000 , 28 ( 4 ) $515-527$.

10. Denhardt, R.B.; Denhardt, J.V. The new public service: serving rather than steering . Public Adm. Rev. 2000 , 60 ( 6 ) 549 - 559 .

11. Fox, C.J. The use of philosophy in administrative ethics . In Handbook of Administrative Ethics ; Cooper, T.L. , Ed.; Marcel Dekker : New York , 2001 , 105 - 130 .

12. Greenaway, J. Having the bun and the halfpenny: can old public service ethics survive in the new whitehall? . Public Adm. 1995, 73 , 357 - 374 .

13. Chapman, R.A. Problems of ethics in public sector management . Public Money Manag. 1998,18 ( 1 ) $9-13$.

14. Chapman, R.A.; O'Toole, B.J. The role of the civil service: a traditional view in a period of change . Public Policy Adm. 1995 , 10 ( 2 ) 3 - 20 .

15. Frederickson, H.G. Public ethics and the new managerialism . Public Integr. 1999 , 1 ( 3 ) $265-278$.

16. Rohr, J.A. Civil Servants and their Constitutions ; University Press of Kansas : Kansas , 2002 , xi. (For examples of this legal criticism on NPM, see, e.g., Cooper, P.J., 2000. Public law and public administration. third edition. Itasca, IL: F.E. Peacock.) .

17. Skidmore, M.J. Ethics and public service . Ann. Am. Acad. Polit. Soc. Sci. 1995 , 537 , $25-36$.

18. Fox, C.J., Miller, H.T., Postmodern Public Administration. Towards Discourse. Thousand Oaks: Sage, 1996.

19. Frederickson, H.G. The Spirit of Public Administration; Jossey-Bass : San Fransisco, CA , 1997,202 .

20. Gawthrop, L.C. Public Service and Democracy ; Chatham House : New York , 1998 , 80

21. Denhardt, K.G. Organizational structure as a context for administrative ethics . In Handbook of Administrative Ethics ; Cooper, T.L. , Ed.; Marcel Dekker : New York , 1994,181 .

22. Osborne, S. The new public governance? Public Management Review 2006, 8 (3) 384

23. Dunleavy, P.; Margrets, H.; Bastow, S.; Tinkler, J. New Public Management is dead Long live digital era governance. Journal of Public Administratio Research \& Theory $2005,16,488$. 
24. Pollitt, C.; Bouckaert, G. Public Management Reform. A Comparative Analysis, New Public Management, Governance, and the Neo-Weberian State. Third edition; Oxford University Press: Oxford, 2011: 22.

25. Maesschalck, J. Approaches to ethics management in the public sector: a proposed extension of the compliance-integrity continuum. Public Integrity 2005, 7 (1), 21-41.

26. OECD . Trust in Government. Ethics Measures in OECD Countries ; OECD : Paris , 2000,25 . 